\title{
NOISE REPORT ONBOARD OF CARGO VESSEL
}

\author{
Elena Gabriela Hulea \\ "Dunărea de Jos" University of Galati, \\ Faculty of Naval Architecture, \\ 47 Domnească Street, 800008, Romania, \\ E-mail: elenagabriela_anton@yahoo.com
}

\author{
Costel Iulian Mocanu \\ "Dunărea de Jos" University of Galati, \\ Faculty of Naval Architecture, \\ 47 Domnească Street, 800008, Romania, \\ E-mail: costel.mocanu@ugal.ro
}

\begin{abstract}
Regarding the increasing demands for a low noise environment onboard ships, the classification societies introduced the measurement of noise levels onboard every ship not only for the first ship, no matter the type and size above 1600 gross tonnage. That why is necessary a good collaboration of all the parties involved in the construction of ships from designers, shipbuilders, till owners. This article describes the measurements technique used for obtaining the noise levels onboard a cargo vessel, to obtain the approval of Classification society.
\end{abstract}

Keywords: Code on noise level onboard ship, permissible levels, sound sources, measurement equipment

\section{INTRODUCTION}

The regulation and limits for maritime vessels, regarding the noise limits, have become more restrictive since the New International Maritime Organization Code (IMO): CODE ON NOISE LEVELS ONBOARD SHIP, MSC 337(91), which is a revision of the old code with the same name, under the name of IMO Resolution A468 (XII) "Code On Noise Levels Onboard Ships". The new version of this regulation, which entered into force for ships under construction from June 1,2014 , aims to prevent crew of hearing loss or damage, to raise necessities crew awareness, for a good communication onboard ship and alarms perception. And also to assure the necessary comfort of crew for rest, relaxation and other spaces and to assure favorable conditions to restore hearing after exposure to noise. All ship-owners must comply with the international regulations for new vessels. Even though noise issues can be controlled it is important for ship-owners to know how to do this in the most efficient and economical way.

(C) Galati University Press, 2020
The prediction of noise level has become very important, due to the negative effects which the acoustic discomfort has on the crew and passengers. The main sources of noise onboard ships are the Main Engine $(\mathrm{M} / \mathrm{E})$ and the propeller. As secondary sources we have diesel generators, air conditioning, ventilation, pumps, compressors, hydraulic systems. Thus, designers, owners, shipyards and ship-owners must have an account of these when adopting measures to limit noise on board the ship.

\section{THE CASE STUDY}

The vessel MV Paula, used for this study, presented in Fig.1...3, is a general cargo ship. This type of ship was designed by S.C. Willemsen Marine Support S.R.L. Galati and built at ATG Giurgiu (for a foreign ship-owner, intended to carry heavy goods in shallow waters) to meet the stringent noise standards. 


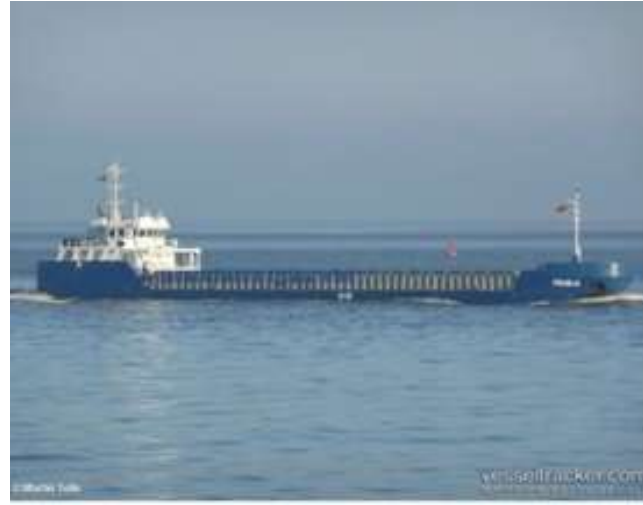

Fig.1. MV Paula Cargo Vessel

Hull:

Length between $\mathrm{pp}$ $87.59 \mathrm{~m}$

Breadth moulded $11.40 \mathrm{~m}$

Depth to main deck $5.50 \mathrm{~m}$

Design draught $3.8 \mathrm{~m}$

Capacities hold $3200 \mathrm{cbm}$

Main engine.

Type

LH 31

Speed. $370 \mathrm{rpm}$

Number of cylinders 6 in line

Power at MCR $1323 \mathrm{~kW}$

Auxiliary engine:

Type 6 CTA8.3-DCM

Speed $1500 \mathrm{rpm}$

Number of cylinders 6 in line

Delivery power $163 \mathrm{~kW}$

Propeller

Number / type

1 / CPP

No. of blades ....4

Diameter $1.90 \mathrm{~m}$

Speed. $370 \mathrm{rpm}$

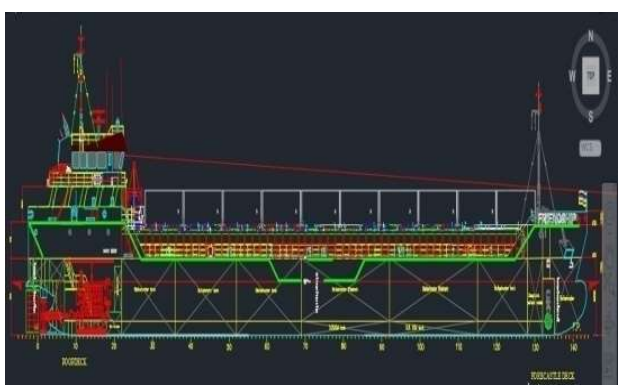

Fig.2. MV Paula side view

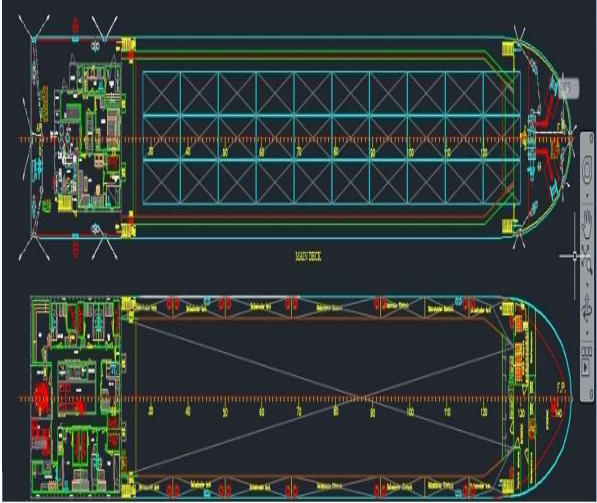

Fig.3. MV Paula top view

\section{MEASUREMENTS CONDITIONS}

The measurements have been performed respecting the regulations of the noise levels register for new ships. Msc 337(91) requirements, which provide the basic recommendation to accomplish de project design taking into consideration the results of sea trial from the ship noise report.

Terminology and calculation formulas The index of sound reduction $\mathrm{R}^{\prime} \mathrm{w}(\mathrm{dB})$ which contains sound insulation performance in sea trial of ship cabins and compartments.

The continuous equivalent sound level

$$
L_{\text {Aeq } T}=10 \log \frac{1}{T} \int_{0}^{\tau} \frac{p_{a}(t)^{2}}{p_{0}{ }^{2}} \cdot d t
$$

$\mathrm{L}_{\text {Aeq( }(\mathrm{T})}(\mathrm{dB}(\mathrm{A})), \mathrm{p}_{\mathrm{a}}(\mathrm{t})=\mathrm{A}$ - sound level pressure equivalent, $\mathrm{T}$ - time interval and $\mathrm{p}_{\mathrm{o}}(20 \mu \mathrm{Pa})$

$$
L_{\text {Ceq }, T}=10 \log \frac{1}{T} \int_{0}^{\tau} \frac{p_{c}(t)^{2}}{p_{0}{ }^{2}} \cdot d t
$$

$\mathrm{L}_{\mathrm{Ceq}}(\mathrm{T})\left(\mathrm{dB}(\mathrm{C}): \mathrm{p}_{\mathrm{C}}(\mathrm{t})=\mathrm{C}\right.$ - the instantaneous sound pressure; $\mathrm{T}$ - time interval, and $\mathrm{p}_{\mathrm{o}}(20 \mu \mathrm{Pa})$

$$
L_{\text {Cpeak }}=10 \log \frac{p_{p e a k^{2}}}{p_{a^{2}}}
$$

The sound pressure level $\mathrm{L}_{\mathrm{p}}$

(C) Galati University Press, 2020 


$$
L_{p}=10 \log \frac{p^{2}}{p_{o^{2}}}
$$

$\mathrm{L}_{\mathrm{p}}(\mathrm{dB}): \mathrm{p}=$ sound pressure $(\mathrm{Pa})$ and $\mathrm{p}_{\mathrm{o}}(20$ $\mu \mathrm{Pa})$.

The measurements have been performed on the Black Sea, in sea trials, in ballast condition in nominal regime, when all the noise sources were operating at nominal parameters.

The characteristics conditions of the sea trials include: operation of the main engine, speed over 12 knots, operation of the propeller. Draught forward $2.7 \mathrm{~m}$, draught aft $3.35 \mathrm{~m}$, wind speed / direction $\left[\mathrm{m} / \mathrm{s} /{ }^{\mathrm{O}} \mathrm{Bf}\right] \sim$ $25 / 3 \mathrm{~m} / \mathrm{s}$ and depth of water $\sim 45.0 \mathrm{~m}$.

The powerful noise is from the Engine Room, because the main engine is running as well as diesel generators for the power generation. The noise of the ventilation system of the rooms operating at maximum capacity will also be taken into account, for measuring the noise of the ventilation on the decks and cabins.

Type and characteristics of measuring instruments. For noise level measurements it has been used the calibrated equipment presented in the below Fig.4:

\begin{tabular}{|c|l|c|}
\hline $\begin{array}{c}\text { Item } \\
\text { no. }\end{array}$ & \multicolumn{1}{|c|}{ Instruments } & Type \\
\hline 1 & Microphone & 4155 \\
\hline 2 & $\begin{array}{l}\text { Sound Level Me- } \\
\text { ter }\end{array}$ & 2250 \\
\hline 3 & Calibrator & 4230 \\
\hline 4 & Wind mask & - \\
\hline 5 & $\begin{array}{l}\text { Utility Software } \\
\text { for Hand-held } \\
\text { Analyzers }\end{array}$ & BZ 5503 \\
\hline 6 & Noise Explorer & 7815 \\
\hline 7 & Notebook & LIFEBOOK E \\
\hline
\end{tabular}

Fig.4. Measurements equipment

We have used the renowned model 2250 of Brüel \& Kjær because can carry out the measurements transmission loss of a ship cabin construction and can offer important absorption index .

\section{MEASUREMENTS ANALISYS}

The measurements have been performed during the ship sailing in straight line (without the rudder heeling) on the Black Sea, with constant speed.

For analysing analyzing noise onboard ship a noise point system is used, which is useful as any other mathematic formula. The points have been established in the representative part of the rooms, according to the different task, that the seafarers must be carried out during a working day. The microphone was placed approx. $10 \mathrm{~cm}$ from the most exposed ear.

Every measurement point is marked with NLn., from wing bridge till floor.

In the calculation have been included bangs (metal against metal), hydraulic noise when using gear and resonance areas.

\begin{tabular}{|c|c|c|c|c|c|c|}
\hline \multicolumn{4}{|c|}{ Measuring point } & \multirow{2}{*}{ 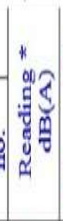 } & \multirow{2}{*}{$\begin{array}{l}\text { Limit } \\
\mathrm{dB}(\mathrm{A})\end{array}$} & \multirow[b]{2}{*}{ Remarks } \\
\hline $\begin{array}{l}0 \\
0 \\
0 \\
0 \\
0 \\
0 \\
\theta_{1}\end{array}$ & Room & $\begin{array}{l}\frac{y}{8} \\
8 \\
\alpha\end{array}$ & $\begin{array}{l}0 \\
0 \\
0 \\
0 \\
\alpha_{4}\end{array}$ & & & \\
\hline 1. & PS Wingbridge & $\mathrm{Nav}$. & & 71.7 & 70 & $(t)^{*}$ NL 1-Fig.6 \\
\hline 2. & Wheellousse & $\mathrm{Nav}$ & & 678 & 65 & (t) $\mathrm{NL} 1-\mathrm{Fig}, 7$ \\
\hline 3. & STB Wingbridge & $\mathrm{Nav}$ & & 71.1 & 70 & $(+)^{+} \mathrm{NL} 3-\mathrm{Fig}, 8$ \\
\hline 4. & Dessroom & Poop & & 64.8 & 65 & $\mathrm{NL} 4-\mathrm{Fig}, 9$ \\
\hline 5 & Captain bedroom & Poop & & 60.7 & 60 & (t) $\mathrm{NL} 5=\mathrm{Fig} .10$ \\
\hline 6. & Captoin dayroom & Poop & & 63.8 & 60 & $(++) \mathrm{NL} 6$ - Figg,1] \\
\hline 1. & $\mathrm{AC}$ room & Poop & & 78.7 & 90 & LL7-Fig 12 \\
\hline 8. & Galley & Main & & 71.3 & 75 & AL8-Fig.13 \\
\hline 9. & Pilot / Onver & Main & & 67.4 & 60 & (H)ML9 - Fig̨,14 \\
\hline 10. & 1 Crew (PS Middle) & Main & & 65.9 & 60 & $(+)$ (L 10 - Fing 15 \\
\hline 11. & 1 Crem (PS Fore) & Main & & 62.2 & 60 & (4).LII-Fig, 16 \\
\hline 12. & Chief mate & Main & & 01.5 & 60 & (†) ML 12-Figl \\
\hline 13. & 1 Crew (STB Fore) & Maili & & 60.2 & 60 & (†) $\mathrm{NL}$ 13-Figl18 \\
\hline 14 & 1 Cren (SIB Middle) & Main & & 0.5 & 60 & (t) IL 14 - Fig, 19 \\
\hline 15. & 1 Crow $(S T B A f i)$ & Miif & & 65.5 & 60 & $(++) \mathrm{NL15}=\mathrm{Fig}, 20$ \\
\hline 16. & Laundry / Changing & Ming & & 76.2 & 85 & NL16-Fig.11 \\
\hline 17. & Steering Gear room & Main & & 92.5 & 90 & (t) MLl7-Fig.42 \\
\hline 18. & Floor in fore side & Floor & & 102.9 & 90 & $(++)$ NL 18-Fig, 23 \\
\hline 19. & Floop in of side & Floot & & 102.0 & 90 & (H) $\mathrm{NL} 19-\mathrm{Fig}, 24$ \\
\hline
\end{tabular}


Fig.5. Measurements results

In the above Fig.5 are shown the results in sea trial at reading column and permissive values at limits column to SOLAS Ch. II-1, Reg. 3-12 Noise Code MSC. 337(91): CODE ON NOISE LEVELS ONBOARD SHIPS.

The values measured in the crew, wing bridge, wheelhouse, AC room, messroom, captain dayroom, steering gear compartment are presented in the next Figure 6...24 (noise levels values in the $1 / 1$ octave band, are exported directly from the sound level meter at the date of the measurements):

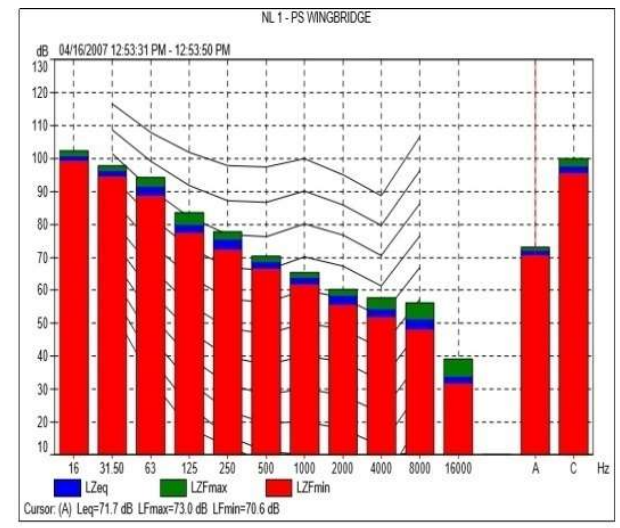

Fig.6. NL 1- PS wingbridge

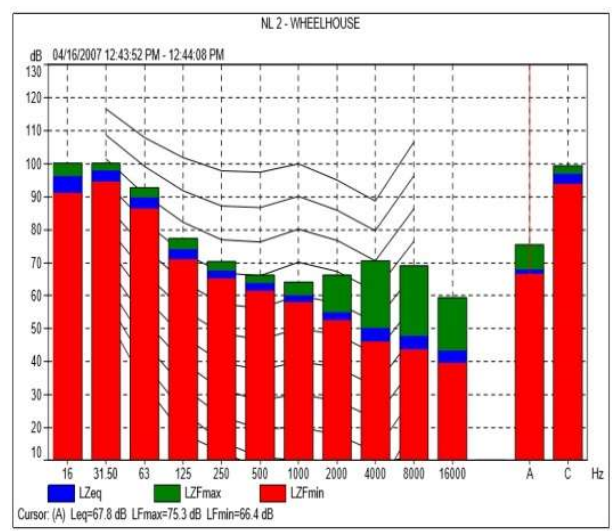

Fig.7. NL 2- Wheelhouse

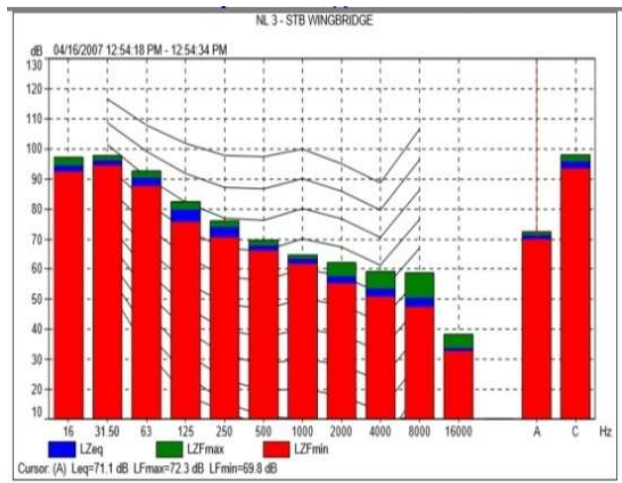

Fig.8. NL 3- STB wingbridge

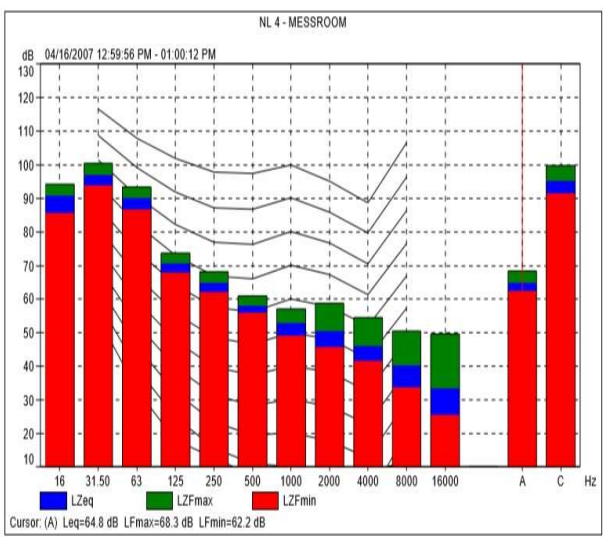

Fig.9. NL 4 - Messroom

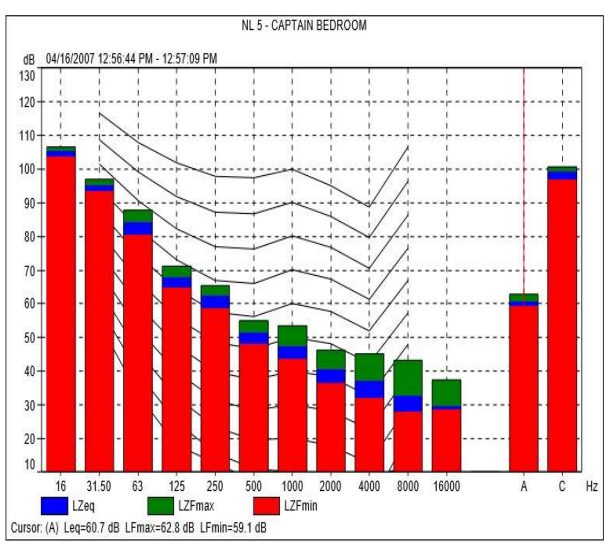

Fig.10. NL 5 - Captain bedroom 


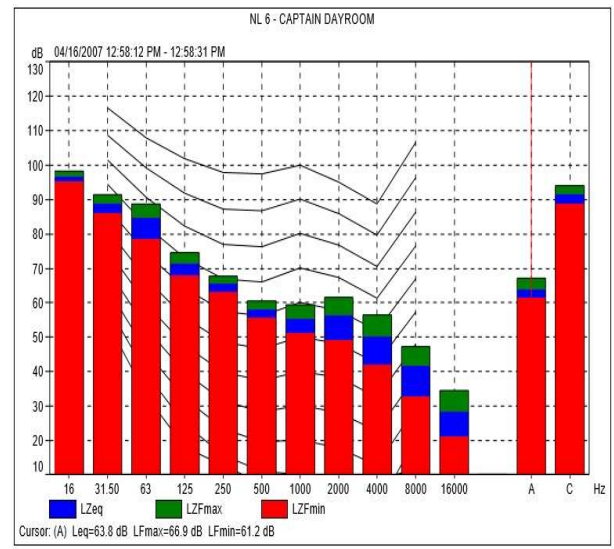

Fig.11. NL 6 - Captain dayroom

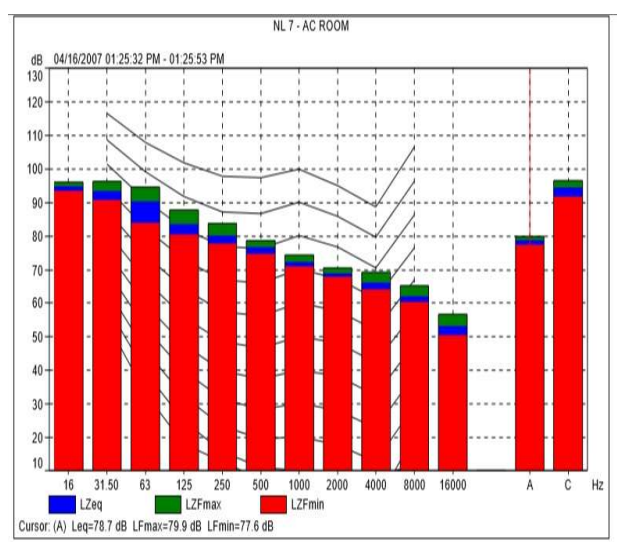

Fig.12. NL7 -AC room

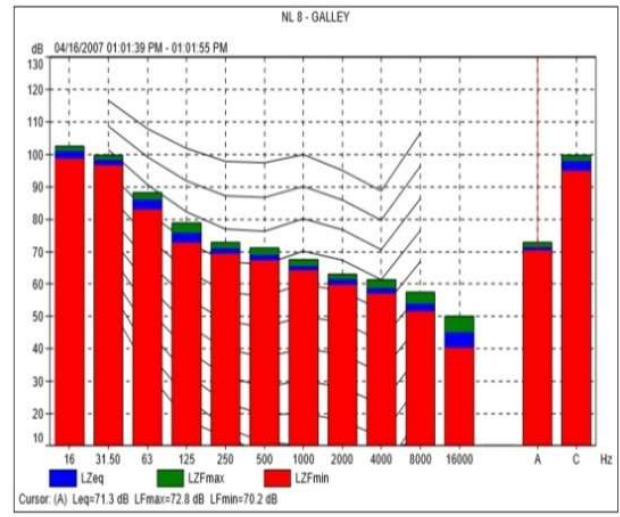

Fig.13. NL8 -Galley

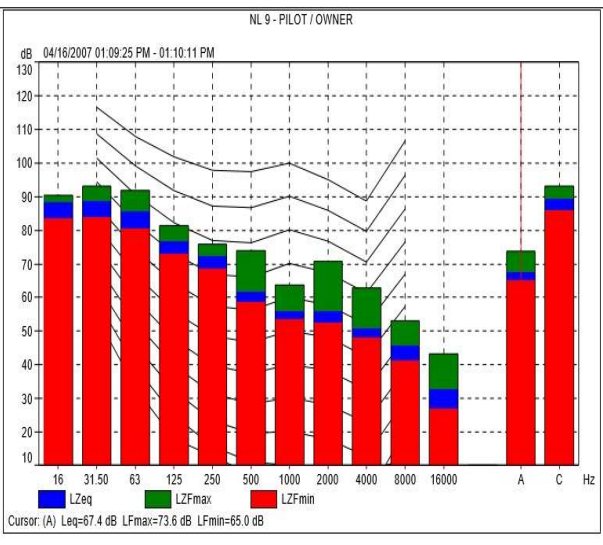

Fig.14. NL9 - Pilot / Owner

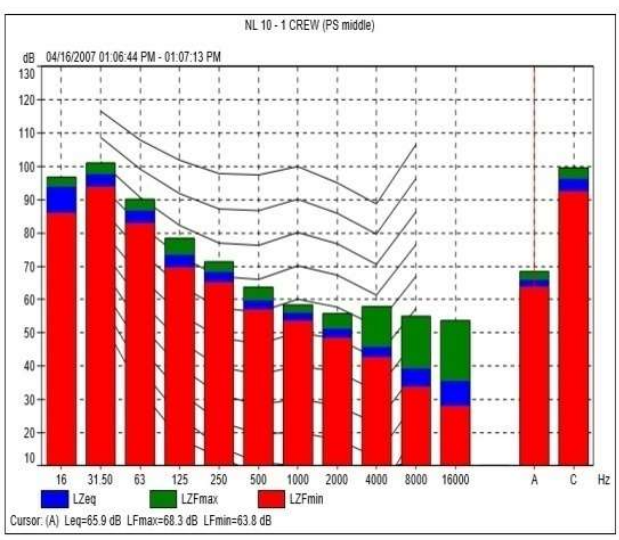

Fig.15. NL 10 - 1 Crew (PS Middle)

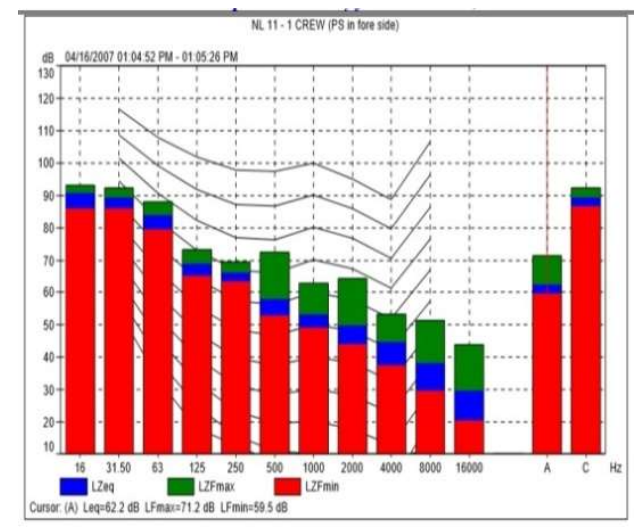

Fig.16. NL 11 - 1 Crew (PS in fore side) 


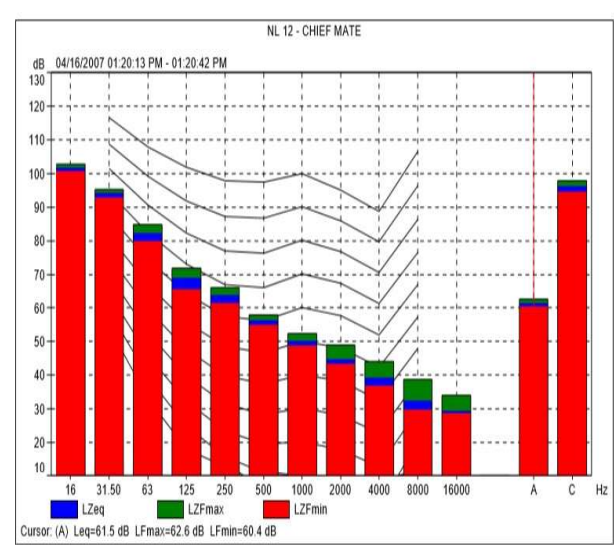

Fig.17. NL 12 - Chief Mate

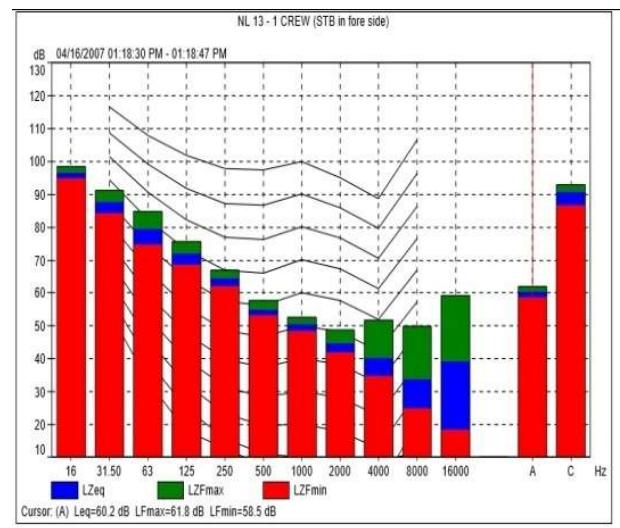

Fig.18. NL13 - 1 Crew (STB in fore side)

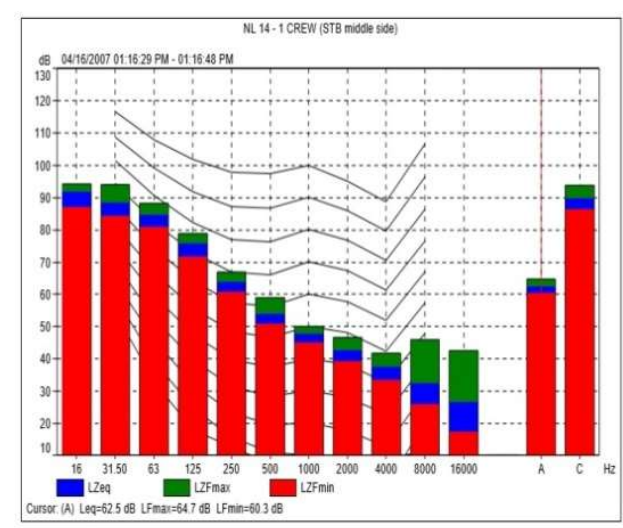

Fig.19. NL14 - 1 Crew (STB Middle)

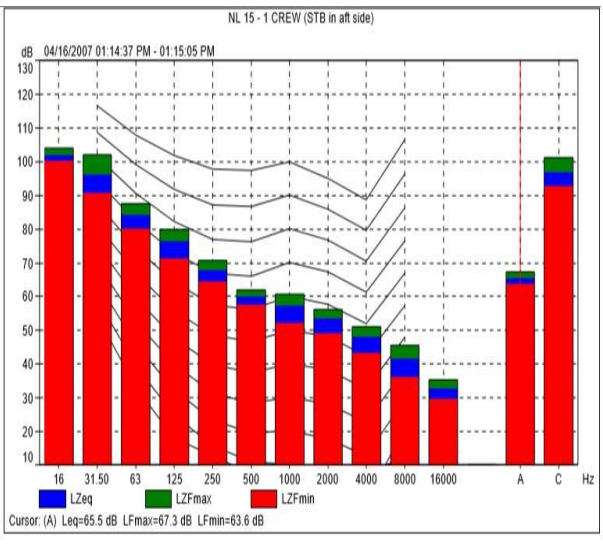

Fig.20. NL15 - 1 Crew (STB in aft side)

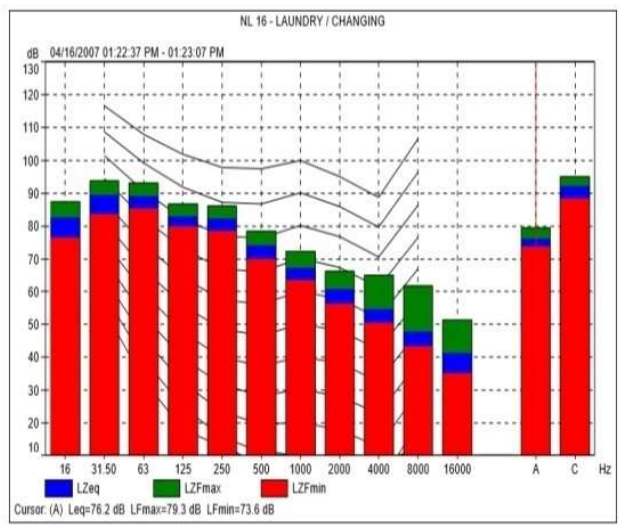

Fig.21. NL 16 - Laundry / Changing

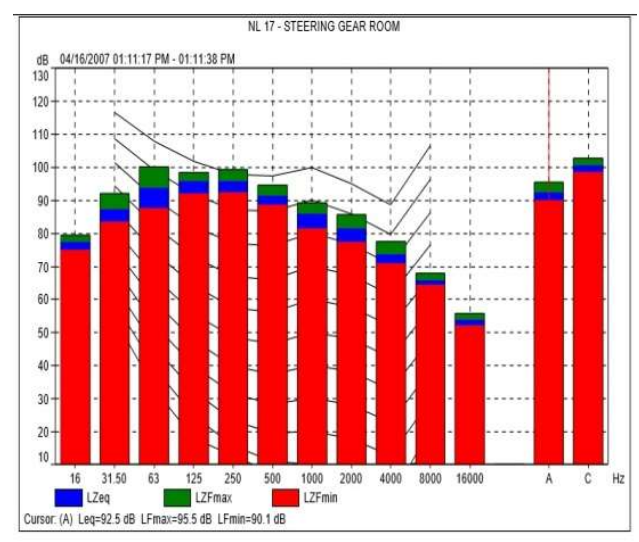

Fig.22. NL 17 - Steering Gear Room

(C) Galati University Press, 2020 


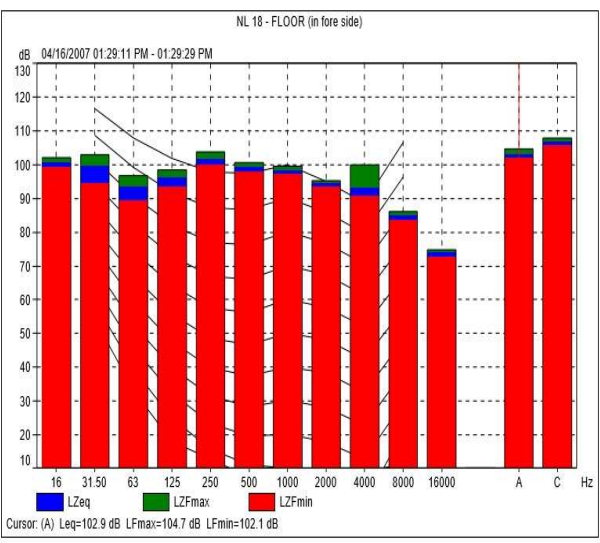

Fig.23. NL 18 - Floor (in fore side)

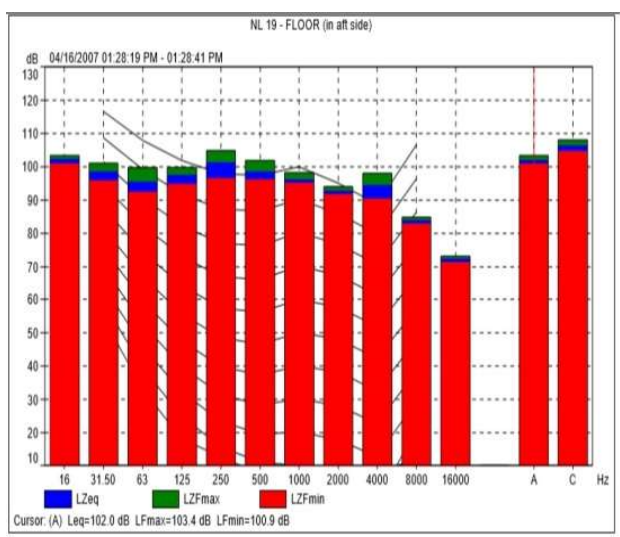

Fig.24 NL19 - Floor (in aft side)

The measurements with the approved and calibrated equipment described in Fig. 4, have been performed in the representative rooms of the ship, and the location of measurements points is presented below Fig. 25...28:

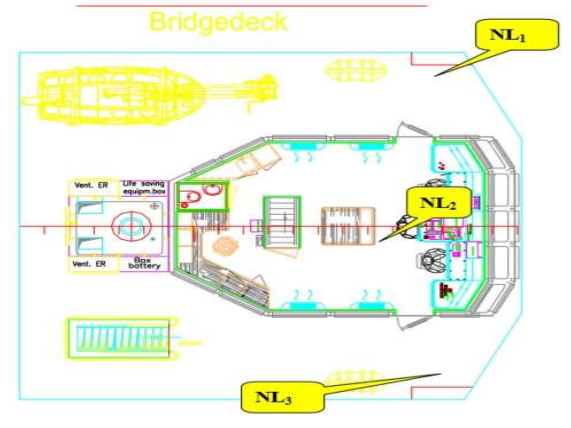

Fig.25. Bridge deck

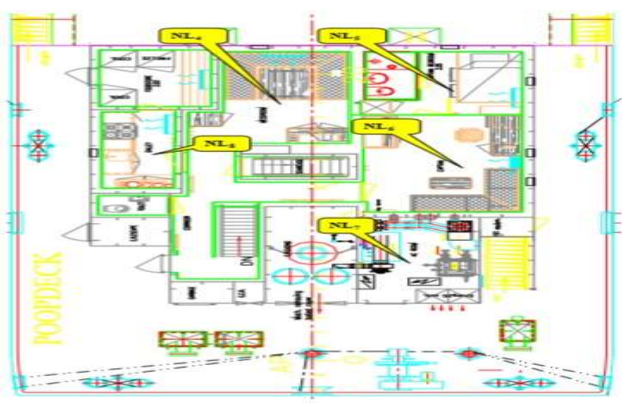

Fig.26. Poop deck

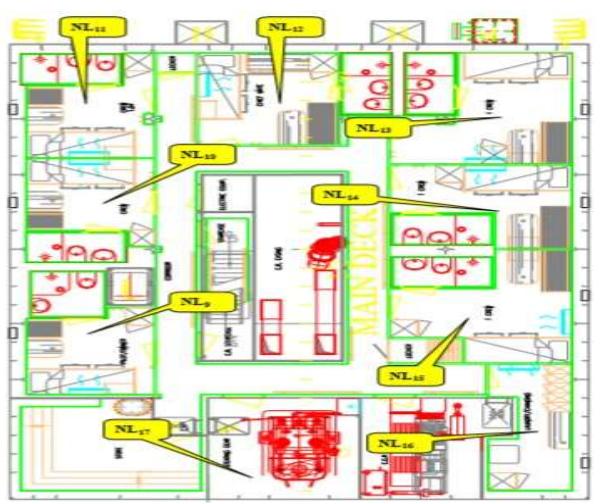

Fig.27. Main deck 


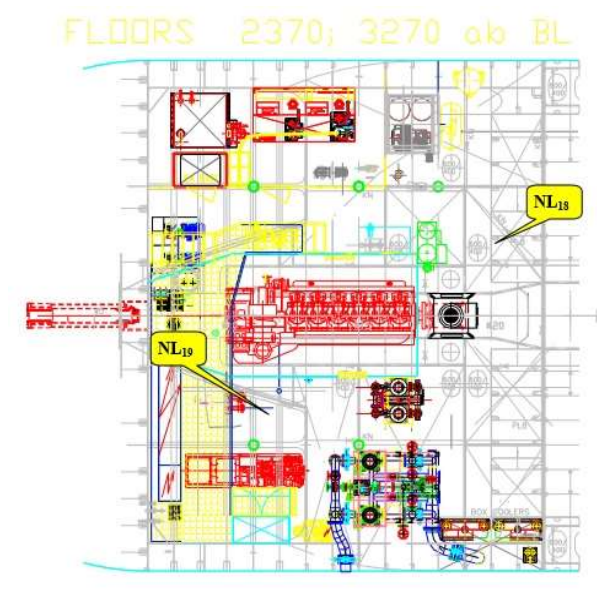

Fig.28. Floor

\section{CONCLUDING REMARKS}

The measurements were performed on the filter of weight "A", according to the above mentioned IMO Resolutions and frequency analysis in $1 / 1$ octave band center. Measurements were performed during the operation at nominal parameters of general ventilation system and air conditioning system of social and living rooms. In addition, the other conditions recommended by mentioned IMO Resolution, were followed.

According Fig.5 the acoustic conditions onboard of this cargo are good for the entire crew, both for the resting cabins and working places.

The good results from the cabins are due to the solutions adopted as: solid rubber mat which has been put on the floor, absorption panels were mounted above the head of the berths and in ceiling of the passage way between the cabins. A heigh influence had the materials chosen for mess construction as solid rubber mats were mounted in lockers, the ceiling and steel bulkheads were insulated with rock wool, also the ceiling was mounted with a flexible joint in top and bottom and frames were insulated off steel.

Remark: because an exceeding up to 3 $\mathrm{dB}(\mathrm{A})$ is acceptable, there are the following measuring points with values above $3 \mathrm{~dB}(\mathrm{~A})$, marked in the table of page \# with $(++)$ :

\begin{tabular}{|c|l|c|}
\hline $\begin{array}{c}\text { Item } \\
\text { no. }\end{array}$ & \multicolumn{1}{|c|}{ Rooms } & Remarks \\
\hline 1 & $\begin{array}{l}\text { NL 6 - room: Cap- } \\
\text { tain dayroom }\end{array}$ & $+3.8 \mathrm{~dB}(\mathrm{~A})$ \\
\hline 2 & $\begin{array}{l}\text { NL 9 - room: } 1 \\
\text { Crew }\end{array}$ & $+7.4 \mathrm{~dB}(\mathrm{~A})$ \\
\hline 3 & $\begin{array}{l}\text { NL 10 - room: } 1 \\
\text { Crew }\end{array}$ & $+5.9 \mathrm{~dB}(\mathrm{~A})$ \\
\hline 4 & $\begin{array}{l}\text { NL 15 - room: } 1 \\
\text { Crew STB aft }\end{array}$ & $+5.5 \mathrm{~dB}(\mathrm{~A})$ \\
\hline 5 & $\begin{array}{l}\text { NL 18 - Floor in } \\
\text { fore side }\end{array}$ & $+12.9 \mathrm{~dB}(\mathrm{~A})$ \\
\hline 6 & $\begin{array}{l}\text { NL 19 - Floor in } \\
\text { aft side }\end{array}$ & $+12.0 \mathrm{~B}(\mathrm{~A})$ \\
\hline
\end{tabular}

Engine Rooms: the admissive noise level is exceeded, being normally regarding the rated power of $\mathrm{M} / \mathrm{E}$; but for an unprotected human ear, according to IMO Resolution A 468 (XII) it is necessary (against the noise dangerous action), on every access doors to Engine Rooms, a warning signal (written on label): is acceptable, there are the following measuring points with values above $3 \mathrm{~dB}(\mathrm{~A})$, marked in the table of page \# with $(++)$ :

WARNING !EXCEEDED NOISE

LEVEL! USE EAR PROTECTORS!

or warning labels, like these:

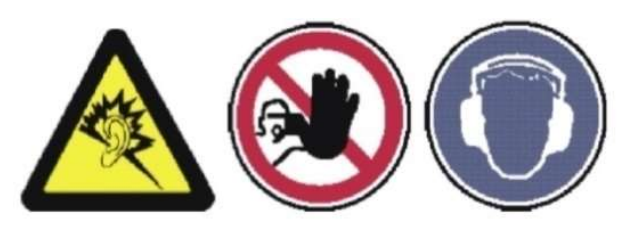

Fig.29. Warning labels

Same labels shall be posted on every access door in spaces having a noise level higher than $85 \mathrm{~dB}(\mathrm{~A})$ like Steering Gear room.

Recommendation: Having in mind this ship has UMS classification, the exceedings recorded in the Engine Room are not important (there are not permanent work places in this compartment). 


\section{Acknowledgements}

The project is based on the results which were mainly obtained from Willemsen Marine Support S.R.L. Company, I am very grateful to co-operate with them.

The author thanks to Mr. Gerrit Willemsen and Mr. Nelu Vizinteanu, the shareholder and the director of the Willemsen Marine Support S.RL. Company, for their entire support.

The work of HULEA (ANTON) ELENA GABRIELA has been funded by the European Social Fund through the Sectoral Operational Programme Human Capital 2014-2020 (in Romanian: Fondul Social European prin Programul Operațional Capital Uman 2014-2020) through the Financial Agreement „Burse pentru educaţia antreprenorială în rândul doctoranzilor şi cercetătorilor postdoctorat (Be Antreprenor!)", Contract No. 51680/09.07.2019- SMIS code: 124539 .

\section{REFERENCES}

[1]. Resolution MSC 337(91) CODE ON NOISE LEVELS ONBOARD SHIPS - November 2012;

[2]. IMO Resolution A 468 (XII) CODE ON NOISE LEVELS ONBOARD SHIPS;

[3]. Willemsen Marine Support S.R.L., Noise Protocol M/V PAULA;

[4]. Willemsen Marine Support S.R.L., Noise Measurements Report onboard M/V PAULA;

[5]. Borelli D., Gaggero T., Badino A., "Noise emited from ships",2012

[6]. Bosoanca, I., Noise Onboard FT MODULE CARRIER VESSEL The Annals Of "Dunarea De Jos" University Of Galati Fascicle Xi Shipbuilding. Issn 1221-4620, 2017

[7]. Det Norske Veritas RULES FOR CLASIFICATION OF SHIPS.

Paper received on April $28^{\text {th }}, 2020$

[1]. $t$ 
